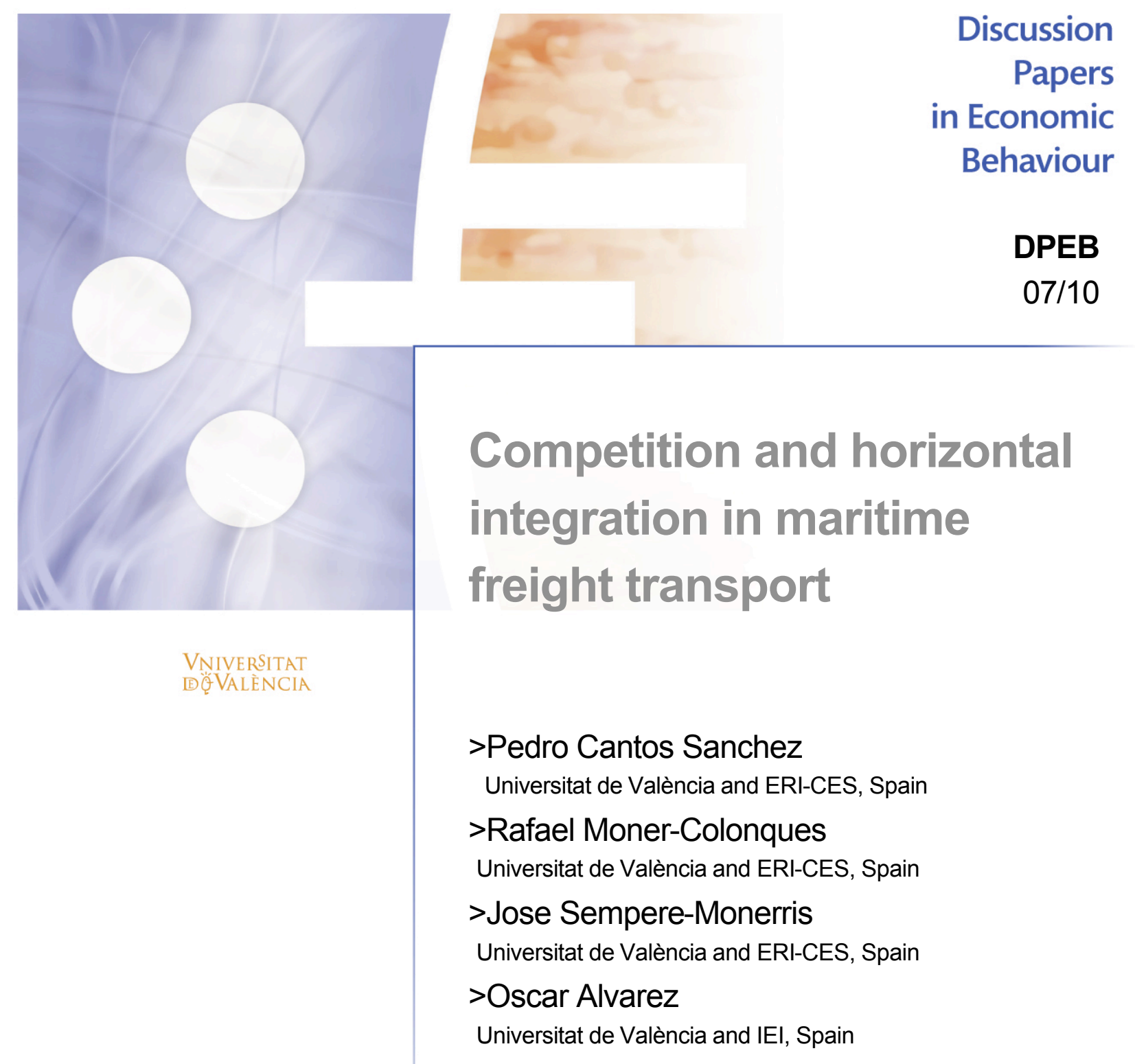




\section{Competition and horizontal integration in maritime freight transport*}

Pedro Cantos-Sanchez ${ }^{1}$, Rafael Moner-Colonques ${ }^{2}$, Jose Sempere-Monerris ${ }^{3}$ and Óscar Alvarez $^{4}$

${ }^{1,2},{ }^{3}$ Department of Economic Analysis and ERI-CES, University of Valencia, Campus dels Tarongers, Avd. dels Tarongers s/n, 46022 Valencia, Spain (e-mail corresponding author: Pedro.Cantos@uv.es)

${ }^{4}$ Department of Economic Analysis and IEI, University of Valencia, Campus dels Tarongers, Avd. dels Tarongers s/n, 46022 Valencia, Spain

Abstract. This paper develops a theoretical model for freight transport characterized by competition between means of transport (the road and maritime sectors), where modes are perceived as differentiated products. Competitive behavior is assumed in the road freight sector, and there are constant returns to scale. In contrast, the freight maritime sector is characterized by oligopolistic behavior, where shipping lines enjoy economies of scale. The market equilibrium where the shipping lines behave as profit maximizers, provides a first approximation to the determinants of market shares, profits, and user welfare. We then characterize the equilibrium when horizontal integration of shipping lines occurs, with and without further economies of scale. An empirical application to the routes ValenciaAntwerp and Valencia-Genoa uncovers that the joint profit of the merged firms and social welfare always increase. However, user surplus only increases when economies of scale are significantly exploited.

Keywords: freight transport, shipping lines, horizontal integration..

\footnotetext{
${ }^{*}$ We gratefully acknowledge financial support from CEDEX, Ministry of Works, under project PT-2007027-01CAPM.
} 


\section{Introduction}

Total road freight transport in Europe is expected to grow by about $60 \%$ by 2013 . This growth would suppose an increase in the negative externalities caused by congestion, accidents, and environmental damage. Consequently, alternative modes to road transport should be used more intensively than hitherto. In fact, seaborne trade in merchandise goods, mainly carried by liner shipping, reached 29.1 trillion ton-miles by 2005 . The development of container shipping has certainly contributed to the increase in maritime traffic, a market with a small number of big shipping lines. The objective of this paper is to develop a freight transport model characterized by competition between road and maritime transport; the model accounts for product differentiation between the two modes and for economies of scale in the shipping line market.

The liner shipping market has a number of characteristics, of which the following stand out. First, there has been an increase in the size of firms and the emergence of global carriers. The top 20 carriers accounted for $71 \%$ of vessel capacity deployed in 2005 . Second, mergers and cooperation agreements have been common in the past few years. Since the 90s, the formation of strategic alliances permits carriers to pool vessels on main commercial routes and profit from scope and network economies. Third, organising the transport of freight by sea involves a number of different agents: freight forwarders, port actors (cargo handlers, stevedores, and shipping agents), shipping companies and inland transport providers. Containerization has paved the way not only to horizontal integration but also to vertical integration in an effort to improve the management of logistics chains. Vertical integration can help companies to reap the benefits of intermodal transport. Despite the increase in this type of structural moves, the biggest shipping lines remain the key actors in transport chains. Fourth, the liner shipping industry exhibits economies of scale, related to the size of the firm as well as to trade density. Fifth, shipping lines are recently becoming more interested in the hinterland transportation sector. The door-todoor service feature acknowledges the relevance of the combination of several transport modes (sea, road, railroad) in the provision of a good service, which means not looking at other transport modes only as competitors.

The model that we propose assumes competition for freight transport between the road and the maritime sectors and captures quite a number of the features that characterize the liner shipping market. In particular, we consider a route with two shipping companies where road transport is supplied competitively. The services offered by operators are perceived as differentiated by shippers. The road transport sector does marginal 
cost pricing whereas the shipping companies hold market power and enjoy economies of scale $^{1}$. We begin by characterizing the equilibrium in this market environment. Results can be intuitively presented in terms of parameters related with product differentiation and with the size of economies of scale. Then we study the effects on fares and market shares when the shipping lines merge (horizontal integration). This is done under two possible scenarios, one with and one without any cost gains. The model is then applied to the route Valencia-Genoa, where Bulcom Intramed Service and Turkon Container Line are the two maritime operators. We use information on travel volumes, price elasticities, and estimates of costs to recover the unknown parameters in the demand functions. We may then study the effects on traffic distribution, prices, profits, and welfare levels under a horizontal integration move.

There is an extensive literature that studies different aspects of maritime transport. The papers by Jansson and Shneerson (1985) and by Song et al. (2005) provide evidence of economies of scale and of network economies, respectively. Heaver et al. (2000) suggests that the extent and form of cooperative agreements, where shipping lines figure prominently, has put them in an excellent negotiating position with port authorities. In a sense, the shipping companies have become much stronger players relative to shippers, stevedores and port authorities. Our model gives shipping lines a relevant role in a setting with strategic price interaction and examines, theoretically and empirically, the effects of horizontal integration. A game-theoretical approach has recently been undertaken by De Borger et al. (2008), who study duopolistic pricing by ports and optimal investment policies in port and hinterland capacity. The recent paper by Cariou (2008) offers an overview of the main trends in the liner shipping market during the last 15 years. The importance of market power and the integration of activities in the maritime sector are made clear by two recent OECD works by Frémont (2009) and Van de Voorde and Vanelslander (2009).

The main results can be summarized as follows. Whether maritime freight increases after the merger is shown to depend on the existence of further economies of scale stemming from the merger process. In case prices for maritime services increase, which occurs when the merger only has strategic effect, road freight transport also increases. Furthermore, under some conditions, horizontal integration is found to be beneficial in private and social terms. The next Section presents the model and theoretical results. Section 3 develops an

\footnotetext{
${ }^{1}$ Panayides (2003) studies the strategy-performance relationship in ship management finding that achieving economies of scale and differentiation (through a wider range of services offered) have a strong influence on performance. The increased emphasis on such relationship is due, among other things, to intense competition (as evidenced by the trend in cooperation already mentioned).
} 
empirical application to the route Valencia-Genoa and Section 4 briefly concludes.

\section{The Model}

Consider a connection between two regions, $A$ and $B$. This connection can be established by two ways. The first one is a long haul truck link, denoted by $t$, that transports the goods from $A$ to $B$, and the other is a combined transport mode in three legs, denoted by $l$. The first leg, a land leg, consists of a truck service delivering the goods from $A$ to one port $H_{A}$. Then, a second leg is sea transport which is delivered by two differentiated shipping lines that carry the goods from port $H_{A}$ to port $H_{B}$ and finally a third land leg, which consists of a truck service delivering the goods from $H_{B}$ to $B .^{2}$ Suppose that users of this transport system consider the two modes $t$ and $l$ as substitutes and also consider as differentiated the services provided by the two shipping lines, denoted by $l 1$ and $l 2$. In this way we model the demand for transport as a system of three linear demand functions as follows:

$$
\begin{aligned}
q_{t} & =a_{t}-f_{t}+\gamma\left(f_{l 1}+f_{l 2}\right) \\
q_{l 1} & =a_{l}-f_{l 1}+\gamma\left(f_{t}+f_{l 2}\right) \\
q_{l 2} & =a_{l}-f_{l 2}+\gamma\left(f_{l 1}+f_{t}\right)
\end{aligned}
$$

where $q_{m}$ is the demand (expressed in Tn-km) corresponding to service $m$, for $m=t$, $l 1, l 2$, also $\alpha_{m}$ corresponds with the maximum level of transport demand for transport mode $m$ and finally, $f_{m}$ is the total price for each mode. In particular, $p_{t}$ is the truck fare per Tn-km, so that $f_{l i}, i=1,2$ is the sum of the truck fares for the first and third legs, $p_{t a}$ and $p_{t b}$ respectively, and the shipping line fares also in Tn-km, $p_{l i}, i=1,2$. We next assume that the truck industries either the long haul or the other two that provide shorter land services are competitive industries in the sense that the equilibrium price is the competitive price, while the shipping line industry is a duopoly that sets prices in a strategic way. Denote by $c_{t}, t_{a}$ and $t_{b}$ the corresponding marginal costs of the long haul, truck $a$ and truck $b$ industries. By the above assumption, $f_{t}=p_{t}=c_{t}, f_{l 1}=t_{a}+t_{b}+p_{l 1}$ and $f_{l 2}=t_{a}+t_{b}+p_{l 2}$, thus we can reformulate the above demand system by defining the constant terms as follows: $\alpha_{t}=a_{t}+2 \gamma\left(t_{a}+t_{b}\right)$, and $\alpha_{l 1}=\alpha_{l 2}=a_{l}-(1-\gamma)\left(t_{a}+t_{b}\right)$. Further note that the system of demand equations must satisfy the condition saying that an increase in the same amount of all prices must imply a decrease in demand; thus $\gamma$ must be smaller than $\frac{1}{2}$. Regarding the shipping line industry, we assume the following cost

\footnotetext{
${ }^{2}$ Roughly speaking, a maritime logistics chain consists of three large sections, the purely maritime activities, goods handling in the port and hinterland transport services. Our model accounts for two of them.
} 
functions: $C_{l i}\left(q_{l i}\right)=c_{i} q_{l i}-\frac{\lambda}{2} q_{l i}^{2}$, with $c_{i}$ and $\lambda>0$, for $i=1,2$, which exhibit increasing returns to scale. ${ }^{3}$ Thus, the extent of the returns to scale is parameterized by $\lambda$, and is assumed that marginal cost are positive, that is $q_{l i}<\frac{c_{i}}{\lambda}$ for all $i$.

We are interested in finding the equilibrium prices, user surplus and social welfare of the transport system and compare this equilibrium with the case where a merger takes place in the shipping line industry, that is, after a horizontal integration move.

i) Initial situation equilibrium

Each shipping company chooses the profit maximizing price, so that shipping line $i$ maximizes $\Pi_{l i}=p_{l i} q_{l i}-c_{i} q_{l i}+\frac{\lambda}{2} q_{l i}^{2}$. Computing the two first order conditions we reach the following system of equilibrium conditions $q_{l i}^{*}=\frac{p_{l i}^{*}-c_{i}}{1-\lambda} i=1,2$ and $p_{t}^{*}=c_{t}$, obtaining the following equilibrium prices:

$p_{l i}^{*}=(1-\lambda)\left(\frac{2\left(\alpha_{t}+\gamma c_{t}\right)-(1-\gamma)\left(c_{1}+c_{2}\right)+(1+\gamma)\left(c_{j}-c_{i}\right)}{2(1+(1-\lambda)(1-\gamma))}\right)+c_{i}$, for $i, j=1,2$ and $i \neq j$.

Note that if $c_{2}>c_{1}$ then $q_{l 2}^{*}\left(c_{1}, c_{2}\right)<q_{l 1}^{*}\left(c_{1}, c_{2}\right)$, and $q_{l 1}^{*} \leq \frac{c_{1}}{\lambda}$ for nonnegative marginal costs. At equilibrium.

$$
\begin{aligned}
q_{t}^{*}\left(c_{1}, c_{2}\right) & =\left(\alpha_{t}-c_{t}+\gamma\left(c_{1}+c_{2}\right)\right)+\gamma(1-\lambda)\left(q_{l 1}^{*}+q_{l 2}^{*}\right), \\
\Pi_{t}^{*}\left(c_{1}, c_{2}\right) & =0, \Pi_{l i}^{*}\left(c_{1}, c_{2}\right)=\left(\frac{2-\lambda}{2}\right)\left(q_{l i}^{*}\right)^{2}, \forall i=1,2 ; \\
U S^{*}\left(c_{1}, c_{2}\right) & =\frac{\left(q_{t}^{*}\right)^{2}+\left(q_{l 1}^{*}\right)^{2}+\left(q_{l 2}^{*}\right)^{2}}{2}, \\
S W^{*}\left(c_{1}, c_{2}\right) & =\frac{\left(q_{t}^{*}\right)^{2}+(3-\lambda)\left(q_{l 1}^{*}\right)^{2}+(3-\lambda)\left(q_{l 2}^{*}\right)^{2}}{2} .
\end{aligned}
$$

The second order condition for a maximum imposes that $\lambda<2$, while stability of equilibrium requires that $0<\gamma<\frac{2-\lambda}{1-\lambda}$, which is a more binding condition on $\lambda$, since $\gamma$ cannot be negative. Therefore we assume that $\lambda<1$.

ii) Horizontal merger: shipping lines 1 and 2 merge.

When both shipping lines decide to merge, several post-merger situations can be reached depending on the way the merger is capable of integrating the former separated production processes. In one of the situations, the new entity sets prices to maximize profits but both cost functions remain separate. In another, the merger can also internalize the returns to scale due to the joint provision of products $q_{l 1}$ and $q_{l 2}$. In fact, the new entity might even profit from synergies that meaning that the post-merger cost function parameters would change so that $c^{\prime} s$ would be smaller or $\lambda$ higher or both things. In the literature of horizontal mergers, the first situation is usually associated with the case where the merger only has strategic effects by the internalization of competition among

\footnotetext{
${ }^{3}$ A linear marginal cost function reflecting increasing returns to scale or traffic density has been employed by Brueckner and Spiller (1991). Constant returns correspond to $\lambda=0$.
} 
shipping line companies. The second situation comprises both a strategic effect and also an efficiency gain due to further exploitation of scale economies, whereas the third case also implies more efficiency because of cost improvements. In this subsection, we will consider the case of symmetric shipping lines, i. e. $c_{1}=c_{2}=c$. Note that the difference between these approaches is easily modelled by looking at the following profit functions:

a) Post-merger situation a: $\Pi_{l 1 l 2}=p_{l 1} q_{l 1}+p_{l 2} q_{l 2}-c\left(q_{l 1}+q_{l 2}\right)+\frac{\lambda}{2}\left(q_{l 1}^{2}+q_{l 2}^{2}\right)$

b) Post-merger situation b: $\Pi_{l 1 l 2}=p_{l 1} q_{l 1}+p_{l 2} q_{l 2}-c\left(q_{l 1}+q_{l 2}\right)+\frac{\lambda}{2}\left(q_{l 1}+q_{l 2}\right)^{2}$

c) Post-merger situation c: $\Pi_{l 1 l 2}=p_{l 1} q_{l 1}+p_{l 2} q_{l 2}-\bar{c}\left(q_{l 1}+q_{l 2}\right)+\frac{\bar{\lambda}}{2}\left(q_{l 1}+q_{l 2}\right)^{2}$, with $\bar{c} \leq c$ and/or $\lambda<\bar{\lambda}$.

We will only consider situations $a$ and $b$.

-Situation a (without further economies of scale).

The new entity chooses the pair of prices $\left(p_{l 1}, p_{l 2}\right)$ to maximize $\Pi_{l 1 l 2}=p_{l 1} q_{l 1}+p_{l 2} q_{l 2}-$ $c\left(q_{l 1}+q_{l 2}\right)+\frac{\lambda}{2}\left(q_{l 1}^{2}+q_{l 2}^{2}\right)$. Then, solving the system formed by $\frac{\partial \Pi_{l 1 l 2}}{\partial p_{l 1}}=0$ and $\frac{\partial \Pi_{l 1 l 2}}{\partial p_{l 2}}=0$, we get that $q_{l 1}^{a}=q_{l 2}^{a}=q_{l}^{a}=\frac{p_{l}^{a}-c}{\left(\frac{1}{1-\gamma}-\lambda\right)}{ }^{4}$. Noting that $p_{t}^{a}=c_{t}$ we obtain the equilibrium prices $p_{l}^{a}=\left(\frac{1}{(1-\gamma)}-\lambda\right) \frac{\left(\left(\alpha_{t}+\gamma c_{t}\right)-(1-\gamma) c\right)}{(2-(1-\gamma) \lambda)}+c$. At equilibrium the other relevant variables are given by:

$$
\begin{aligned}
q_{t}^{a} & =\left(\alpha_{t}-c_{t}+2 \gamma c\right)+2 \gamma\left(\frac{1}{(1-\gamma)}-\lambda\right) q_{l}^{a}, \\
\Pi_{l 112}^{a} & =2\left(p_{l}^{a}-c\right)\left(q_{l}^{a}\right)+\lambda\left(q_{l}^{a}\right)^{2}=\left(\frac{2}{(1-\gamma)}-\lambda\right)\left(q_{l}^{a}\right)^{2}, \\
U S^{a} & =\frac{\left(q_{t}^{a}\right)^{2}}{2}+\left(q_{l}^{a}\right)^{2}, \\
S W^{a} & =\frac{\left(q_{t}^{a}\right)^{2}}{2}+\left(\frac{2}{(1-\gamma)}+(1-\lambda)\right)\left(q_{l}^{a}\right)^{2} .
\end{aligned}
$$

-Situation $b$ (with further economies of scale).

The new entity chooses the pair of prices $\left(p_{l 1}, p_{l 2}\right)$ to maximize $\Pi_{l 1 l 2}=p_{l 1} q_{l 1}+p_{l 2} q_{l 2}-$ $c\left(q_{l 1}+q_{l 2}\right)+\frac{\lambda}{2}\left(q_{l 1}+q_{l 2}\right)^{2}$. Then, solving for $\frac{\partial \Pi_{l 1 l 2}}{\partial p_{l 1}}=0$ and $\frac{\partial \Pi_{l 1 l 2}}{\partial p_{l 1}}=0$, we get, for the symmetric cost case, that $q_{l 1}^{b}=q_{l 2}^{b}=q_{l}^{b}=\frac{p_{l}^{b}-c}{\left(\frac{1}{1-\gamma}-2 \lambda\right)}{ }^{5}$. As above noting that $p_{t}^{b}=c_{t}$, the equilibrium shipping prices $p_{l}^{b}=\left(\frac{1}{(1-\gamma)}-2 \lambda\right) \frac{\left(\left(\alpha_{t}+\gamma c_{t}\right)-(1-\gamma) c\right)}{2(1-(1-\gamma) \lambda)}+c$. The other relevant

\footnotetext{
${ }^{4}$ Global second order conditions are satisfied for $\lambda<1$, since $\lambda<1<\frac{2}{1+\gamma^{2}}$, which implies that the determinant of the Hessian matrix is positive.

${ }^{5}$ As above global second order conditions are satisfied for $\lambda<1$, since $\lambda<1<\frac{2}{(1-\gamma)^{2}}$, and the corresponding determinant of the Hessian matrix is positive as $\lambda<1<\frac{1}{(1-\gamma)}$.
} 
variables are given by:

$$
\begin{aligned}
q_{t}^{b} & =\left(\alpha_{t}-c_{t}+2 \gamma c\right)+2 \gamma\left(\frac{1}{(1-\gamma)}-2 \lambda\right) q_{l}^{b} \\
\Pi_{l 112}^{b} & =2\left(p_{l}^{b}-c\right)\left(q_{l}^{b}\right)+2 \lambda\left(q_{l}^{b}\right)^{2}=2\left(\frac{1}{(1-\gamma)}-\lambda\right)\left(q_{l}^{b}\right)^{2}, \\
U S^{b} & =\frac{\left(q_{t}^{b}\right)^{2}}{2}+\left(q_{l}^{b}\right)^{2} \\
S W^{b} & =\frac{\left(q_{t}^{b}\right)^{2}}{2}+\left(\frac{2}{(1-\gamma)}+(1-2 \lambda)\right)\left(q_{l}^{b}\right)^{2} .
\end{aligned}
$$

\section{Some Results}

We are first interested in finding how shipping traffic evolves after one of the proposed merger situations occurs. It is easy to prove the next result for the symmetric case $c_{1}=$ $c_{2}=c$.

Result 1: Either $q_{l}^{a}<q_{l}^{b}<q_{l}^{*}$ if $\lambda \in\left(0, \frac{\gamma}{1+\gamma}\right)$, or $q_{l}^{a}<q_{l}^{*}<q_{l}^{b}$ if $\lambda \in\left(\frac{\gamma}{1+\gamma}, 1\right)$.

The proof is straightforward just noting that $q_{l}^{*}=\frac{\left(\alpha_{t}+\gamma c_{t}\right)-(1-\gamma) c}{1+(1-\gamma)(1-\lambda)}, q_{l}^{a}=\frac{\left(\alpha_{t}+\gamma c_{t}\right)-(1-\gamma) c}{(2-(1-\gamma) \lambda)}$ and $q_{l}^{b}=\frac{\left(\alpha_{t}+\gamma c_{t}\right)-(1-\gamma) c}{2(1-(1-\gamma) \lambda)}$, then the ranking holds for $0<\lambda<1,0<\gamma<\frac{1}{2}$. The merger with only strategic effect internalizes the competition among the shipping lines thus implying a positive marginal profit at the pre-merger equilibrium price. Thus a higher price is attained at the post-merger equilibrium and then output falls. Alternatively, if the merger incorporates further scale effects then the marginal profit after the merger includes a new negative term that induces post-merger equilibrium prices to fall in case it dominates the previous positive effect, i.e. if $\lambda>\frac{\gamma}{1+\gamma}$, so that total output increases.

Note that for each merger situation to happen we need to ensure that it is privately profitable and also that the new entity finds it profitable to keep both differentiated services operative. Private profitability is ensured as long as $2 \Pi_{l i}^{*}\left(c_{1}, c_{2}\right)<\Pi_{l 1 l 2}^{a}$ and $2 \Pi_{l i}^{*}\left(c_{1}, c_{2}\right)<$ $\Pi_{l 1 l 2}^{b}$. The next result ensures that both merger types are privately profitable for $c_{1}=c_{2}=$ $c$ :

Result 2: $2 \Pi_{l i}^{*}(c, c)<\Pi_{l 1 l 2}^{a}<\Pi_{l 1 l 2}^{b}$.

The proof is also straightforward. Just note that the merger with only strategic effects implies less output as compared with the initial situation, but the increase in market power is enough to outweigh the output reduction with an increase in the margin thus leading to greater profits. The merger with a better use of scale economies is even more profitable since it yields both an output and a margin increase at equilibrium. Also note that since the long haul truck transport is a competitive industry, Result 2 proves that any of the two types of merger increases firms' profits. 
The next feature to evaluate is how the long haul traffic varies as a function of the shipping line market structure.

Result 3: a) $q_{t}^{a}$ is greater than both $q_{t}^{*}$ and $q_{t}^{b}$. b) $q_{t}^{b}$ is greater than $q_{t}^{*}$ if and only if $\left.0<\lambda<\frac{1}{2(1-\gamma)}\right\}$, otherwise $q_{t}^{*}$ is greater than $q_{t}^{b}$, with $\gamma<\frac{1}{2}$, and $\lambda<1$.

Since the long haul truck industry behaves in a competitive way, prices are not reacting to the varying pricing conditions in the shipping line industry. Thus, final long haul output for each shipping line market structure is fully explained by the shipping line prices. Therefore, the greater the equilibrium shipping line prices the higher the long haul output. Since prices are higher in the merger with only strategic effects as compared to both the initial situation and the merger with further scale economies, then a merger with only strategic effects implies the higher level of truck transport. Whether the merger with further economies of scale implies higher level of truck transport than the one in the initial situation depends on either low $\lambda$ or high $\gamma$.

Result 4: A sufficient condition for $S W^{b}>S W^{*}$ to hold is $\frac{\gamma}{1-\gamma}<\lambda$ and $\lambda<$ $\min \left\{\frac{2 \gamma}{1-\gamma}, \frac{1}{2(1-\gamma)}\right)$. Similarly a sufficient condition for $U S^{b}>U S^{*}$ is $\frac{\gamma}{1-\gamma}<\lambda<\frac{1}{2(1-\gamma)}$.

The above result, which is directly obtained from Results 1 and 3, indicates that for low levels of scale economies the merger with further economies of scale can generate an increase in the equilibrium of both the maritime transport and long haul truck transport. This is enough to lead to an increase in user and social surplus. Remind, $\lambda<\frac{1}{2(1-\gamma)}$ implies $q_{t}^{b}>q_{t}^{*}$, and $\frac{\gamma}{1-\gamma}<\lambda$ implies $q_{l}^{b}>q_{l}^{*}$. The consideration of $\lambda<\frac{2 \gamma}{1-\gamma}$ has to do with the comparison between the second terms in the respective social welfare functions, $\left(\frac{2}{(1-\gamma)}+(1-2 \lambda)\right)\left(q_{l}^{b}\right)^{2}$ and $(3-\lambda)\left(q_{l}^{*}\right)^{2}$. If $\lambda<\frac{2 \gamma}{1-\gamma}$, then $(2+(1-\gamma)(1-2 \lambda))>(3-\lambda)(1-\gamma)$.

Result 5: A sufficient condition for $S W^{a}>S W^{*}$ is $\lambda<\Psi(\gamma)$, where $\Psi(\gamma)$ increases in $\gamma, \Psi(\gamma=0.3907570)=0$. and $\Psi\left(\gamma=\frac{1}{2}\right)=1$.

The precise expression for $\Psi(\gamma)$ is $\frac{-2+\gamma\left(5+9 \gamma-4 \gamma^{2}\right)-\sqrt{4-20 \gamma+53 \gamma^{2}-70 \gamma^{3}+41 \gamma^{4}+8 \gamma^{5}+16 \gamma^{6}}}{8(1-\gamma) \gamma^{2}}$. Result 5 indicates that low levels of scale economies together with high cross elasticities imply that the increase in the long haul transport induced by the merger more than compensates the reduction in maritime transport so that aggregate user welfare increases and since firms' profits also increase, total welfare goes in the same direction. Finally and considering a symmetric situation in the sense that $\alpha_{t}=\alpha_{l}$ and $c_{t}=c$, we provide the necesary and sufficient condidions for $S W^{a}$ exceeds $S W^{*}$. In particular, for $0<\lambda<\Omega(\gamma)$, where $\Omega(\gamma)$ is an increasing function in $\gamma, \Omega(\gamma=0.251221)=0$ and $\Omega\left(\gamma=\frac{1}{2}\right)=0.347296$. Note that $\Omega(\gamma)=\frac{-2+\gamma\left(13-\gamma-2 \gamma^{2}\right)-\sqrt{4-20 \gamma+53 \gamma^{2}-74 \gamma^{3}+53 \gamma^{4}+12 \gamma^{5}+4 \gamma^{6}}}{4(1-\gamma) \gamma^{2}}$. Given that, if $\gamma<0.251221$, then $S W^{a}<S W^{*}$ for all $\lambda$ while if $\gamma>0.347296$, then $S W^{a}>S W^{*}$ for all $\lambda$. 


\section{Empirical application}

In this section we are going to calibrate the theoretical model using actual data from two particular routes between the Spanish port of Valencia and the ports of Antwerp and Genoa. In boths routes there are two shipping lines which offer maritime freight transport between the two ports, and both services are differentiated. The average capacity is slightly different, and more importantly, the frequency of the two companies for each route is different as well. Besides we also have data about road traffic supplied by trucking companies between the region of Valencia (Spain) and the region of Flandre (Belgium) and the region of Liguria (Italy), respectively. In particular, the number of Tons transported by road and by each shipping line in 2007 were the following:

[Insert Table 1 about here]

Regarding costs, the truck industry costs can be calculated from official data obtained from "Observatorio del coste del transporte de mercancías por carretera 2008, Ministry of Works". Specifically, the cost per vehicle km of a standard truck (carrying a 20 Tn capacity container) is estimated to be $0.9 €$. We do not have any available data on maritime costs, but we provide information about the average shipping prices for sending a $20 \mathrm{Tn}$ container between the ports of Valencia-Antwerp and Valencia-Genoa. This average price can be obtained from an electronic simulator, a public program provided by the Spanish Ministry of Works. Then the parameters $c$ and $\lambda$ in the cost equation are calibrated in order to obtain equilibrium prices similar to those provided by the simulator. The final values used for $c$ and $\lambda$ are 0.55 and $0.1 €$ per 20 Tn container $\mathrm{km}$, respectively.

Finally, we need estimates for the own and cross-price elasticities. In the calibration we will consider different elasticities for road and shipping transport, and therefore, we will obtain values for the parameters in the demand expressions above. We employ the data from the paper by Beuthe et al (2001):

\section{[Insert Table 2 about here]}

With all these data, the calibration follows a two stage process:

1. We first identify the demand elasticities in the following asymmetric system: $q_{t}=$ $\bar{\alpha}_{t}-\beta_{t} p_{t}+\bar{\gamma}\left(p_{l 1}+p_{l 2}\right), q_{l 1}=\bar{\alpha}_{l 1}-\beta_{l} p_{l 1}+\bar{\gamma}\left(p_{t}+p_{l 2}\right), q_{l 2}=\bar{\alpha}_{l 2}-\beta_{l} p_{l 2}+\bar{\gamma}\left(p_{l 1}+p_{t}\right)$. Note that the model developed has assumed, for simplicity, symmetry in own effects and next a normalization of the coefficents so that the coefficients of prices are 1 and $\gamma$. By expressing quantities and prices in logarithms, the coefficients are the values of the elasticities. Therefore, a system of three equations with three unknowns can be solved to obtain the values of $\beta_{t}, \beta_{l}$ and $\gamma$. 
2. In the next step, values for $\bar{\alpha}_{t}, \bar{\alpha}_{l 1}$ and $\bar{\alpha}_{l 2}$ are calibrated. To do so, we take the equilibrium expressions for quantities in the initial case and set them equal to the values of 20 Tn Container km transported (in logs). We can then solve a system of three equations to estimate a value for $\bar{\alpha}_{t}, \bar{\alpha}_{l 1}$ and $\bar{\alpha}_{l 2}$.

With all these calibrated values we can obtain prices and quantities in logarithm, which can be appropriately transformed in levels of $€$ per container $\mathrm{km}$ and thousands of containers $\mathrm{km}$. We can also calculate the results for the different scenarios. Table 3 column 1 reports the results for the initial case, whereas columns 2 and 3 report the results under horizontal merger without and with further economies of scale.

[Insert Tables 3 and 4 about here]

Firstly, we are going to comment the results for the route Valencia-Antwerp. In table 3, $\lambda=0.1$ stands for the situation where economies of scale are very important. In the event of merger, this parameter represents around one third of total costs saving. We also assume that $d=0.6$, thus considering that services are weakly differentiated. Regarding the two types of merger, prices increase and the aggregate profits of the merged shipping lines are higher than the sum of profits before merger; the firms always have strong incentives to merge. We also obtain that consumer surplus and social welfare are maximal in the merger with no economies. This outcome is explained by the strong increase in freight traffic of the competitive trucking sector. Finally, using data from INFRAS/IWW (2004), we can estimate the negative externalities provoked by road and maritime freight transport. The net social welfare, taking into account these estimates are reported in the last row. ${ }^{6}$ When $\lambda=0.01$ (see table 4 where $\lambda$ now represents a cost saving of $3.33 \%$ in the merger situation) the results in terms of prices and traffic levels change slighlty as compared with table 3 , and therefore, the social gains of the merger (without and with further economies) are always significant.

However, when $d=0.075$ (see tables 5 and 6 ), this meaning that servicies between road and shipping are clearly more differentiated, the changes in prices and traffic levels are very small with respect to the pre-merger scenario. Now the social gains from the merger are lower, and again these gains are, as expected, more relevant when the shipping lines can better exploit their economies of scale. Social welfare in the pre-merger regime and the merger regime without further economies are now very similar in tables 5 and 6 .

\footnotetext{
${ }^{6}$ We have considered that the average externality cost transported by a $20 \mathrm{Tn}$ truck container is 1.42 $€$ per $\mathrm{km}$. The same number of tons transported by shipping lines supposes $0.45 €$ per $\mathrm{km}$.
} 
[Insert Tables 5 and 6 about here]

Secondly, regarding the second route, Valencia-Genoa, the results are qualitatively similar to those obtained for the route Valencia-Antwerp (see tables 7 to 10). Again the social gains are higher in the merger scenarios when the services provided by road and shipping lines are less differentiated. Summing up, we can conclude that product diffentiation (approximated by the parameter of cross elasticity) seems more relevant in our results than the parameter of economies of scale.

[Insert Tables 7 to 10 about here]

\section{Conclusions}

We have developed a theoretical model where the maritime sector, assumed oligopolistic, competes for freight transport with a competitive road transport industry. Attention is drawn to product differentiation and the size of economies of scale in the characterization of market equilibrium without and with horizontal integration between shipping lines. It is shown that maritime freight increases after the merger in case it entails further economies of scale. In case prices for maritime services increase, which occurs when the merger only has a strategic effect, road freight transport also increases. Furthermore, under some conditions, horizontal integration is found to be beneficial in private and social terms.

In the empirical application we have employed data for two freight routes between the hinterland of Valencia and the hinterlands of Genoa and Antwerp. The results show that, in all cases examined, the shipping lines have strong incentives to merge. Additionally, a merger (horizontal integration) between two shipping lines where economies of scale are further exploited generally leads to an increase in social welfare. Also, in most of the cases, the merger produces a significant increase in road traffic, which is greater than the reduction in traffic transported by the shipping lines, and this fact leads to an increase in user surplus. We have obtained that the social gains depend mainly of the characteristics of the market. Then the social gains obtained with the merger are higher in those markets where the road and shipping services are less differentiated. If the services are clearly differentiated, then the social gains are significantly lower.

There are many possible extensions that we wish to undertake in the future. It would be interesting to analyze the situation if the trucking companies do not behave competitively. Also we would like to study the possibility that lines can share the capacity of their vessels, instead of supplying its own ones. Also it is interesting to consider asymmetric costs, incorporating, for instance, economies in the size of the vessels. And finally, the 
analysis of potential vertical integration, for example, between some trucking companies and the shipping lines is another line of future research.

\section{References}

[1] Beuthe, M., B. Jourquin, J-F Geerts, C. Koul and N. Ha (2001). "Freight transportation demand elasticities: a geographic multimodal transportation network analyisis". Transportation Research Part E 37, 253-266.

[2] Brueckner, J. K. and P. T. Spiller (1991). 'Competition and Mergers in Airline Networks', International Journal of Industrial Organization, 9, 323-42.

[3] Cariou, P. (2008), Liner shipping strategies: an overview, International Journal of Ocean Systems Management, 1, 2-13.

[4] De Borger, B., S. Proost and K. Van Dender (2008), "Private Port Pricing and Public Investment in Port and Hinterland Capacity ", Journal of Transport Economics and Policy, 42, 3, 527-561.

[5] Frémont, A., (2009), "Empirical evidence for integration and disintegration of maritime shipping, port and logistics activities", OECD/ITF Discussion paper 20091.

[6] Heaver, T., H. Meersman, F. Moglia and E. Van de Voorde (2000), Do mergers and alliances influence European shipping and port competition?, Maritime Policy and Management, 27, 4, 363-373.

[7] INFRAS/IWW (2004), "External Cost of Transport. Update Study. Final Report". Zurich/Karlsruhe.

[8] Jansson, J.O. and D. Shneerson (1985), Economies of trade density in liner shipping and optimal pricing, Journal of Transport Economics and Policy,

[9] Panayides, P. (2003), "Competitive strategies and organizational performance in ship management", Maritime Policy and Management, 30, 2, 123-140.

[10] Song, D., Zhang, J., Carter, J., Field, T, Marshall, J., Polak, J., Schumacher, K., Sinha-Ray, P. and J. Woods (2005), On cost-efficiency of the global container shipping network", Maritime Policy and Management, 32, 1, 15-30.

[11] Van de Voorde, E. And Vanelslander, T. (2009), Market power and vertical and horizontal integration in the maritime shipping and port industry, OECD/ITF discussion paper 2009-2. 
Table 1. Number of tons transported

\begin{tabular}{|l|r|r|}
\hline & Valencia-Antwerp & Valencia-Genoa \\
\hline Trucking companies & 590490 & 25914 \\
\hline Shipping line 1 & 73561 & 24562 \\
\hline Shipping line 2 & 207976 & 53487 \\
\hline Total & 872027 & 103963 \\
\hline
\end{tabular}

Table 2. Values of elasticities

Road own price elasticity -1.31

Shipping own price elasticity -1.38

Cross elasticity $0.6-0.075$

\section{VALENCIA-ANTWERP}

Table 3. VALENCIA-ANTWERP. Results with $\lambda=0.1$ and cross elasticity $=0.6$

\begin{tabular}{|c|c|c|c|}
\hline & No merger & $\begin{array}{l}\text { Merger (no further } \\
\text { economies) }\end{array}$ & $\begin{array}{l}\text { Merger (with further } \\
\text { economies) }\end{array}$ \\
\hline $\begin{array}{l}\text { Truck price }(€ \text { per } \\
\text { container-km) }\end{array}$ & 0.900 & 0.900 & 0.900 \\
\hline $\begin{array}{l}\text { Price line } 1 \text { ( } € \text { per } \\
\text { container-km) }\end{array}$ & 0.558 & 0.759 & 0.714 \\
\hline $\begin{array}{l}\text { Price line } 2(€ \text { per } \\
\text { container-km) }\end{array}$ & 1.069 & 1.269 & 1.275 \\
\hline $\begin{array}{l}\text { Road Quantity } \\
\text { (thousands) }\end{array}$ & $53,144.2$ & $70,840.1$ & $68,479.2$ \\
\hline $\begin{array}{l}\text { Line } 1 \text { quantity } \\
\text { (thousands) }\end{array}$ & $11,938.9$ & $8,749.1$ & $9,548.6$ \\
\hline $\begin{array}{l}\text { Line } 2 \text { quantity } \\
\text { (thousands) }\end{array}$ & $33,754.5$ & $32,611.2$ & $31,122.9$ \\
\hline Total quantity & $98,837.6$ & $112,200.4$ & $109,150.7$ \\
\hline $\begin{array}{l}\text { Profits line 1 } \\
\text { (thousands of } € \text { ) }\end{array}$ & \multirow{3}{*}{$2,490.4$} & \multirow[b]{3}{*}{$3,305.9$} & \multirow[b]{3}{*}{$3,444.6$} \\
\hline $\begin{array}{l}\text { Profits line } 2 \\
\text { (thousands of } € \text { ) }\end{array}$ & & & \\
\hline $\begin{array}{l}\text { Profits merge } \\
\text { (thousands of } € \text { ) }\end{array}$ & & & \\
\hline $\begin{array}{l}\text { User Surplus } \\
\text { (thousands of } € \text { ) }\end{array}$ & $65,669.6$ & $98,678.6$ & $92,123.6$ \\
\hline $\begin{array}{l}\text { Social welfare } \\
\text { (thousands of } € \text { ) }\end{array}$ & $68,301.2$ & $101,984.5$ & $95,568.2$ \\
\hline Externalities & $9,602.7$ & $11,920.5$ & $11,554.3$ \\
\hline Net social welfare & $58,698.5$ & $90,064.5$ & $84,013.9$ \\
\hline
\end{tabular}


Table 4. VALENCIA-ANTWERP. Results with $\lambda=0.01$ and cross elasticity $=0.6$

\begin{tabular}{|c|c|c|c|}
\hline & No merger & $\begin{array}{l}\text { Merger (no further } \\
\text { economies) }\end{array}$ & $\begin{array}{l}\text { Merger (with further } \\
\text { economies) }\end{array}$ \\
\hline $\begin{array}{l}\text { Truck price ( } € \text { per } \\
\text { container-km) }\end{array}$ & 0.900 & 0.900 & 0.900 \\
\hline $\begin{array}{l}\text { Price line } 1(€ \text { per } \\
\text { container-km) }\end{array}$ & 0.567 & 0.761 & 0.756 \\
\hline $\begin{array}{l}\text { Price line } 2(€ \text { per } \\
\text { container-km) }\end{array}$ & 1.192 & 1.414 & 1.415 \\
\hline $\begin{array}{l}\text { Road Quantity } \\
\text { (thousands) }\end{array}$ & $53,144.2$ & $70,180.4$ & $69,956.0$ \\
\hline $\begin{array}{l}\text { Line } 1 \text { quantity } \\
\text { (thousands) }\end{array}$ & $11,938.9$ & $8,911.9$ & $8,987.9$ \\
\hline $\begin{array}{l}\text { Line } 2 \text { quantity } \\
\text { (thousands) }\end{array}$ & $33,754.5$ & $32,377.6$ & $32,227.2$ \\
\hline Total quantity & $98,837.6$ & $111,469.6$ & $111,171.1$ \\
\hline $\begin{array}{l}\text { Profits line } 1 \\
\text { (thousands of } € \text { ) }\end{array}$ & 87.7 & & \\
\hline $\begin{array}{l}\text { Profits line } 2 \\
\text { (thousands of } € \text { ) }\end{array}$ & $2,395.2$ & & \\
\hline $\begin{array}{l}\text { Profits merge } \\
\text { (thousands of } € \text { ) }\end{array}$ & & $3,248.3$ & $3,263.6$ \\
\hline $\begin{array}{l}\text { User Surplus } \\
\text { (thousands of } € \text { ) }\end{array}$ & $65,559.6$ & 96.988 .8 & $96,351.5$ \\
\hline $\begin{array}{l}\text { Social welfare } \\
\text { (thousands of } € \text { ) }\end{array}$ & $68,152.5$ & $100,237.1$ & $99,615.1$ \\
\hline Externalities & $9,602.7$ & $11,823.6$ & $11,788.4$ \\
\hline Net social welfare & $58,549.8$ & $88,413.5$ & $87,826.7$ \\
\hline
\end{tabular}


Table 5. VALENCIA-ANTWERP. Results with $\lambda=0.1$ and cross elasticity $=0.075$

\begin{tabular}{|c|c|c|c|}
\hline & No merger & $\begin{array}{l}\text { Merger (no further } \\
\text { economies) }\end{array}$ & $\begin{array}{l}\text { Merger (with further } \\
\text { economies) }\end{array}$ \\
\hline $\begin{array}{l}\text { Truck price }(€ \text { per } \\
\text { container-km) }\end{array}$ & 0.900 & 0.900 & 0.900 \\
\hline $\begin{array}{l}\text { Price line } 1(€ \text { per } \\
\text { container-km) }\end{array}$ & 0.559 & 0.574 & 0.538 \\
\hline $\begin{array}{l}\text { Price line } 2(€ \text { per } \\
\text { container-km) }\end{array}$ & 1.069 & 1.075 & 1.061 \\
\hline $\begin{array}{l}\text { Road Quantity } \\
\text { (thousands) }\end{array}$ & $53,144.2$ & $53,275.5$ & $52,966.2$ \\
\hline $\begin{array}{l}\text { Line } 1 \text { quantity } \\
\text { (thousands) }\end{array}$ & $11,938.9$ & $11,499.6$ & $12,577.4$ \\
\hline $\begin{array}{l}\text { Line } 2 \text { quantity } \\
\text { (thousands) }\end{array}$ & $33,754.5$ & $33,575.9$ & $33,961.2$ \\
\hline Total quantity & $98,837.6$ & $98,351.0$ & $99,504.8$ \\
\hline $\begin{array}{l}\text { Profits line } 1 \\
\text { (thousands of } € \text { ) }\end{array}$ & \multirow{3}{*}{$2,490.3$} & \multirow[b]{3}{*}{$2,645.1$} & \multirow[b]{3}{*}{$3,038.8$} \\
\hline $\begin{array}{l}\text { Profits line } 2 \\
\text { (thousands of } € \text { ) }\end{array}$ & & & \\
\hline $\begin{array}{l}\text { Profits merge } \\
\text { (thousands of } € \text { ) }\end{array}$ & & & \\
\hline $\begin{array}{l}\text { User Surplus } \\
\text { (thousands of } € \text { ) }\end{array}$ & $15,527.8$ & $15,500.0$ & $15,563.3$ \\
\hline $\begin{array}{l}\text { Social welfare } \\
\text { (thousands of } € \text { ) }\end{array}$ & $18,159.9$ & $18,145.1$ & $18,602.1$ \\
\hline Externalities & $9,602.7$ & $9,593.5$ & $9,615.4$ \\
\hline Net social welfare & $8,557.2$ & $8,551.6$ & $8,986.7$ \\
\hline
\end{tabular}


Table 6. VALENCIA-ANTWERP. Results with $\lambda=0.01$ and cross elasticity $=0.075$

\begin{tabular}{|c|c|c|c|}
\hline & No merger & $\begin{array}{l}\text { Merger (no further } \\
\text { economies) }\end{array}$ & $\begin{array}{l}\text { Merger (with further } \\
\text { economies) }\end{array}$ \\
\hline $\begin{array}{l}\text { Truck price }(€ \text { per } \\
\text { container-km) }\end{array}$ & 0.900 & 0.900 & 0.900 \\
\hline $\begin{array}{l}\text { Price line } 1(€ \text { per } \\
\text { container-km) }\end{array}$ & 0.567 & 0.582 & 0.579 \\
\hline $\begin{array}{l}\text { Price line } 2(€ \text { per } \\
\text { container-km) }\end{array}$ & 1.192 & 1.199 & 1.198 \\
\hline $\begin{array}{l}\text { Road Quantity } \\
\text { (thousands) }\end{array}$ & $53,144.2$ & $53,266.7$ & $53,240.3$ \\
\hline $\begin{array}{l}\text { Line } 1 \text { quantity } \\
\text { (thousands) }\end{array}$ & $11,938.9$ & $11,499.6$ & $11,623.1$ \\
\hline $\begin{array}{l}\text { Line } 2 \text { quantity } \\
\text { (thousands) }\end{array}$ & $33,754.5$ & $33,575.9$ & $33,601.2$ \\
\hline Total quantity & $98,837.6$ & $98,342.2$ & $98,464.6$ \\
\hline $\begin{array}{l}\text { Profits line } 1 \\
\text { (thousands of } € \text { ) }\end{array}$ & 87.7 & & \\
\hline $\begin{array}{l}\text { Profits line } 2 \\
\text { (thousands of } € \text { ) }\end{array}$ & $2,395.2$ & & \\
\hline $\begin{array}{l}\text { Profits merge } \\
\text { (thousands of } € \text { ) }\end{array}$ & & $2,505.0$ & $2,539.2$ \\
\hline $\begin{array}{l}\text { User Surplus } \\
\text { (thousands of } € \text { ) }\end{array}$ & $15,527.7$ & $15,500.7$ & $15,502.2$ \\
\hline $\begin{array}{l}\text { Social welfare } \\
\text { (thousands of } € \text { ) }\end{array}$ & $18,010.6$ & $18,005.7$ & $18,041.4$ \\
\hline Externalities & $9,602.7$ & $9,593.9$ & $9,595.2$ \\
\hline Net social welfare & $8,407.9$ & $8,411.8$ & $8,446.2$ \\
\hline
\end{tabular}




\section{VALENCIA GENOA}

Table 7. VALENCIA-GENOA. Results with $\lambda=0.1$ and cross elasticity $=0.6$

\begin{tabular}{|c|c|c|c|}
\hline & No merger & $\begin{array}{l}\text { Merger (no further } \\
\text { economies) }\end{array}$ & $\begin{array}{l}\text { Merger (with further } \\
\text { economies) }\end{array}$ \\
\hline $\begin{array}{l}\text { Truck price }(€ \text { per } \\
\text { container-km) }\end{array}$ & 0.900 & 0.900 & 0.900 \\
\hline $\begin{array}{l}\text { Price line } 1(€ \text { per } \\
\text { container-km) }\end{array}$ & 0.514 & 0.629 & 0.603 \\
\hline $\begin{array}{l}\text { Price line } 2(€ \text { per } \\
\text { container-km) }\end{array}$ & 0.862 & 0.949 & 0.955 \\
\hline $\begin{array}{l}\text { Road Quantity } \\
\text { (thousands) }\end{array}$ & $1,592.42$ & $1,902.54$ & $1,862.69$ \\
\hline $\begin{array}{l}\text { Line } 1 \text { quantity } \\
\text { (thousands) }\end{array}$ & $1,043.88$ & 851.26 & 903.26 \\
\hline $\begin{array}{l}\text { Line } 2 \text { quantity } \\
\text { (thousands) }\end{array}$ & $2,273.20$ & $2,264.05$ & $2,187.17$ \\
\hline Total quantity & $4,909.50$ & $5,017.85$ & $4,953.12$ \\
\hline $\begin{array}{l}\text { Profits line } 1 \\
\text { (thousands of } € \text { ) }\end{array}$ & 69.56 & & \\
\hline $\begin{array}{l}\text { Profits line } 2 \\
\text { (thousands of } € \text { ) }\end{array}$ & $1,081.45$ & & \\
\hline $\begin{array}{l}\text { Profits merge } \\
\text { (thousands of } € \text { ) }\end{array}$ & & $1,418.79$ & $1,566.76$ \\
\hline $\begin{array}{l}\text { User Surplus } \\
\text { (thousands of } € \text { ) }\end{array}$ & $16,050.10$ & $17,289.70$ & $16,557.60$ \\
\hline $\begin{array}{l}\text { Social welfare } \\
\text { (thousands of } € \text { ) }\end{array}$ & $17,201.11$ & $18,708.49$ & $18,124.36$ \\
\hline Externalities & $3,753.92$ & $4,103.49$ & $4,035.71$ \\
\hline Net social welfare & $13,447.19$ & $14,605.00$ & $14,088.65$ \\
\hline
\end{tabular}


Table 8. VALENCIA-GENOA. Results with $\lambda=0.01$ and cross elasticity $=0.6$

\begin{tabular}{|c|c|c|c|}
\hline & No merger & $\begin{array}{l}\text { Merger (no further } \\
\text { economies) }\end{array}$ & $\begin{array}{l}\text { Merger (with further } \\
\text { economies) }\end{array}$ \\
\hline $\begin{array}{l}\text { Truck price }(€ \text { per } \\
\text { container-km) }\end{array}$ & 0.900 & 0.900 & 0.900 \\
\hline $\begin{array}{l}\text { Price line } 1(€ \text { per } \\
\text { container-km) }\end{array}$ & 0.516 & 0.625 & 0.623 \\
\hline $\begin{array}{l}\text { Price line } 2(€ \text { per } \\
\text { container-km) }\end{array}$ & 0.928 & 1.022 & 1.022 \\
\hline $\begin{array}{l}\text { Road Quantity } \\
\text { (thousands) }\end{array}$ & $1,592.42$ & $1,891.84$ & $1,888.06$ \\
\hline $\begin{array}{l}\text { Line } 1 \text { quantity } \\
\text { (thousands) }\end{array}$ & $1,043.88$ & 861.55 & 866.54 \\
\hline $\begin{array}{l}\text { Line } 2 \text { quantity } \\
\text { (thousands) }\end{array}$ & $2,273.20$ & $2,251.81$ & $2,244.08$ \\
\hline Total quantity & $4,909.50$ & $5,005.20$ & $4,998.68$ \\
\hline $\begin{array}{l}\text { Profits line } 1 \\
\text { (thousands of } € \text { ) }\end{array}$ & \multirow{3}{*}{$\begin{array}{r}22.61 \\
999.24\end{array}$} & \multirow[b]{3}{*}{$1,311.84$} & \multirow[b]{3}{*}{$1,327.23$} \\
\hline $\begin{array}{l}\text { Profits line } 2 \\
\text { (thousands of } € \text { ) }\end{array}$ & & & \\
\hline $\begin{array}{l}\text { Profits merge } \\
\text { (thousands of } € \text { ) }\end{array}$ & & & \\
\hline $\begin{array}{l}\text { User Surplus } \\
\text { (thousands of } € \text { ) }\end{array}$ & $16,050.10$ & $17,146.90$ & $17,073.10$ \\
\hline $\begin{array}{l}\text { Social welfare } \\
\text { (thousands of } € \text { ) }\end{array}$ & $17,071.95$ & $18,458.74$ & $18,400.33$ \\
\hline Externalities & $3,753.92$ & $4,087.43$ & $4,080.83$ \\
\hline Net social welfare & $13,318.03$ & $14,371.31$ & $14,319.50$ \\
\hline
\end{tabular}


Table 9. VALENCIA-GENOA. Results with $\lambda=0.1$ cross elasticity $=0.075$

\begin{tabular}{|c|c|c|c|}
\hline & No merger & $\begin{array}{l}\text { Merger (no further } \\
\text { economies) }\end{array}$ & $\begin{array}{l}\text { Merger (with further } \\
\text { economies) }\end{array}$ \\
\hline $\begin{array}{l}\text { Truck price }(€ \text { per } \\
\text { container-km) }\end{array}$ & 0.900 & 0.900 & 0.900 \\
\hline $\begin{array}{l}\text { Price line } 1(€ \text { per } \\
\text { container-km) }\end{array}$ & 0.514 & 0.523 & 0.513 \\
\hline $\begin{array}{l}\text { Price line } 2(€ \text { per } \\
\text { container-km) }\end{array}$ & 0.835 & 0.837 & 0.833 \\
\hline $\begin{array}{l}\text { Road Quantity } \\
\text { (thousands) }\end{array}$ & $1,592.42$ & $1,594.85$ & $1,589.11$ \\
\hline $\begin{array}{l}\text { Line } 1 \text { quantity } \\
\text { (thousands) }\end{array}$ & $1,043.88$ & $1,017.78$ & $1,081.35$ \\
\hline $\begin{array}{l}\text { Line } 2 \text { quantity } \\
\text { (thousands) }\end{array}$ & $2,273.20$ & $2,270.43$ & $2,275.07$ \\
\hline Total quantity & $4,909.50$ & $4,838.06$ & $4,945.53$ \\
\hline $\begin{array}{l}\text { Profits line } 1 \\
\text { (thousands of } € \text { ) }\end{array}$ & 68.67 & & \\
\hline $\begin{array}{l}\text { Profits line } 2 \\
\text { (thousands of } € \text { ) }\end{array}$ & $1,020.12$ & & \\
\hline $\begin{array}{l}\text { Profits merge } \\
\text { (thousands of } € \text { ) }\end{array}$ & & $1,097.62$ & $1,322.35$ \\
\hline $\begin{array}{l}\text { User Surplus } \\
\text { (thousands of } € \text { ) }\end{array}$ & $3,256.85$ & $3,235.63$ & $3,284.96$ \\
\hline $\begin{array}{l}\text { Social welfare } \\
\text { (thousands of } € \text { ) }\end{array}$ & $4,345.65$ & $4,333.25$ & $4,607.31$ \\
\hline Externalities & $3,753.92$ & $3,744.39$ & $3,766.92$ \\
\hline Net social welfare & 591.73 & 588.86 & 840.39 \\
\hline
\end{tabular}


Table 10. VALENCIA-GENOA. Results with $\lambda=0.01$ and cross elasticity $=0.075$

\begin{tabular}{|c|c|c|c|}
\hline & No merger & $\begin{array}{l}\text { Merger (no further } \\
\text { economies) }\end{array}$ & $\begin{array}{l}\text { Merger (with further } \\
\text { economies) }\end{array}$ \\
\hline $\begin{array}{l}\text { Truck price }(€ \text { per } \\
\text { container-km) }\end{array}$ & 0.900 & 0.900 & 0.900 \\
\hline $\begin{array}{l}\text { Price line } 1(€ \text { per } \\
\text { container-km) }\end{array}$ & 0.516 & 0.525 & 0.522 \\
\hline $\begin{array}{l}\text { Price line } 2(€ \text { per } \\
\text { container-km) }\end{array}$ & 0.899 & 0.901 & 0.901 \\
\hline $\begin{array}{l}\text { Road Quantity } \\
\text { (thousands) }\end{array}$ & $1,592.42$ & $1,594.71$ & $1,594.20$ \\
\hline $\begin{array}{l}\text { Line } 1 \text { quantity } \\
\text { (thousands) }\end{array}$ & $1,043.88$ & $1,019.39$ & $1,025.20$ \\
\hline $\begin{array}{l}\text { Line } 2 \text { quantity } \\
\text { (thousands) }\end{array}$ & $2,273.20$ & $2,270.40$ & $2,270.04$ \\
\hline Total quantity & $4,909.50$ & $4,839.50$ & $4,889.44$ \\
\hline $\begin{array}{l}\text { Profits line } 1 \\
\text { (thousands of } € \text { ) }\end{array}$ & \multirow{3}{*}{933.20} & \multirow[b]{3}{*}{966.139} & \multirow[b]{3}{*}{986.99} \\
\hline $\begin{array}{l}\text { Profits line } 2 \\
\text { (thousands of } € \text { ) }\end{array}$ & & & \\
\hline $\begin{array}{l}\text { Profits merge } \\
\text { (thousands of } € \text { ) }\end{array}$ & & & \\
\hline $\begin{array}{l}\text { User Surplus } \\
\text { (thousands of } € \text { ) }\end{array}$ & $3,256.85$ & $3,236.59$ & $3,239.71$ \\
\hline $\begin{array}{l}\text { Social welfare } \\
\text { (thousands of } € \text { ) }\end{array}$ & $4,211.77$ & $4,202.73$ & $4,226.71$ \\
\hline Externalities & $3,753.92$ & $3,744.89$ & $3,746.63$ \\
\hline Net social welfare & 457.85 & 457.83 & 480.08 \\
\hline
\end{tabular}

